\title{
Challenges of COVID Standard Operating Procedure Compliance in a Secondary Private School
}

\author{
Ahmad Ubaidah, Azlin Norhaini Mansor, Harwati Hashim \\ Faculty of Education, Universiti Kebangsaan, Selangor, Malaysia \\ Email: azlinmansor@ukm.edu.my
}

How to cite this paper: Ubaidah, A., Mansor, A. N., \& Hashim, H. (2021). Challenges of COVID Standard Operating Procedure Compliance in a Secondary Private School. Creative Education, 12, 1881-1890. https://doi.org/10.4236/ce.2021.128143

Received: July 7, 2021

Accepted: August 9, 2021

Published: August 12, 2021

Copyright $\odot 2021$ by author(s) and Scientific Research Publishing Inc. This work is licensed under the Creative Commons Attribution International License (CC BY 4.0).

http://creativecommons.org/licenses/by/4.0/

\begin{abstract}
The implementation of the standard operating procedures (SOP) at school did not go smoothly as expected because the schools are facing challenges in term of facilities and workforce. Most of the students are unable to maintain physical distancing and obey the SOP compliance as well as teachers faced challenges in observing them most of the time. Hence, this study aims to find out whether private schools are facing challenges or not despite having better facilities and workforce. Six teachers from a private school have participated in this research and data collected through interview. The data was synthesised by using thematic and narrative analysis. The findings of the research show that the private schools also face challenges in SOP compliance and have difficulties in terms of facilities as well as workforce in order to carry out SOP successfully.
\end{abstract}

\section{Keywords}

Standard Operating Procedures (SOP), Compliance, Private School, COVID-19

\section{Introduction}

By the end of December 2019, a new infectious respiratory disease appeared in Wuhan, China, and the World Health Organization (WHO) named it the COVID-19 virus. WHO declared the outbreak of the pandemic a global health emergency and global concern on January 30, 2020 (Ahmed et al., 2021) and total lockdown was imposed in Malaysia for a period of time. During the lockdown, Ministry of Education (MOE) stated that the teaching and learning platform will be done via online and gave guidelines included access to communications technology among teachers, parents and students. After months of plan- 
ning to reopen the school, MOE gave guidelines to all schools to ensure compliance with the standard operating procedures (SOP) set by the Ministry of Health $(\mathrm{MOH})$, as well as the school reopening management guidelines (Malay Mail, 2020).

However, the implementation of the SOP at school did not go smoothly as planned although it was expected that all the students would adhere to the SOP as most of them were frustrated because of the online lessons. There were not enough spaces available at school in order to maintain physical distancing and so many teachers were needed in order to observe the SOP compliance by the students. Other than that, high number of students in most school made the issue become worst as so many students have to wait in queue just to get into the school (Mohamed-Haflah et al., 2021). Some of the issues had receded after the management of schools were able to improve in the new norm but the other issues were still worrying as schools would be the first victims if another COVID-19 outbreak occurred. This is because of the SOP compliance was still feeble although the teachers were trying their best.

Hence, this led to another question: Are all schools facing challenges in SOP compliance? There were lots of complaints made by all the parties including parents and students about the negligence in obeying the SOP because of several factors such as stated above. Those issues mostly came from government schools and private schools were said to have less issues as they have better facilities and resources to carry out the SOP according to $\mathrm{MOH}$ guidelines. This study attempts to find out the challenges faced by a private secondary school regarding SOP compliance.

\section{Research Purpose}

The purpose of this study is to find out whether private school is also facing problems in SOP compliance nevertheless having better resources as well as facilities compared to other schools. This research will also give some insights on what are the challenges faced by private school as well as suggestions to overcome them.

\section{Research Questions}

Two research questions were constructed to explore the challenges of SOP compliance faced by private schools.

1) What are the challenges that teachers face during SOP compliance in private schools?

2) What are the suggestions to overcome the challenges?

\section{Literature Review}

\subsection{Schools during Pandemic}

Malaysia Movement Control Order (MCO) was implemented in order to isolate the source of the COVID-19 outbreak (Abdullah et al., 2020), eventually result- 
ing in the closure of all schools and education institutions. Based on the data provided by The United Nations Educational, Scientific and Cultural Organization (UNESCO), more than half of student population around the world has been affected by the school closure due to COVID-19 pandemic (Tamin \& Mohamad, 2020).

Additionally, the quality of education was diminishing,

"The global education community continues to face the major challenge of providing interactive and motivating educational experience during school and university closure." (Huang et al., 2020).

This led to reopening of schools in Malaysia starting 15th July 2020 but in stages (Idris et al., 2020). In the article, the Minister of Education stated that one of the major reason that lead to such decision is because majority of students are unable to participate in e-learning session during the lockdown and drastic measures have to be taken in order to ensure the education of the students.

\subsection{COVID Standard Operating Procedures (SOP)}

The guidelines on school management and operation in the new norms by the MOE were preceded with reopening of school on 4th June 2020. Specific and special rules were implemented in order to maintain the precautions according to $\mathrm{MOH}$ (Kementerian Pendidikan Malaysia, 2020). Teachers were ordered to attend prior to the reopening in order to do the preparation needed. All the school facilities as well as classroom were rearranged in order for the students to practice physical distancing. Specific SOP was mentioned for the students' meal break too where foods will be sent to the classes and teachers have to monitor them.

\subsection{Problems Faced by Schools}

One of the major problems was, getting negative perceptions from the parents when MOE announced that they will focus the teaching and learning (PDP) for the Malaysian Certificate of Education (SPM) candidates because the other students were having lots of problems during e-learning at home and cannot wait for their turn at school (Sababathy, 2021). According to (Arifin, 2020), when the some school have to implement schedule rotation and some parents assumed it is not fair. Too much time spent on measuring student's temperature and user-friendly thermometer was not available. Classroom's size was not practical for physical distancing and students felt uncomfortable during lesson. Most of the students unable to practice physical distancing when they meet their friends especially during meal time and schools were unable to take actions when students do not obey SOP outside of the school gate.

\subsection{Differences between Government and Private Schools}

According to Anastasiou and Garametsi (2021), private schools have better management and resources for education needs. This can be seen in Malaysia 
where parents are willing to pay expensive monthly fees compared to yearly fees for government school which is very affordable. One of the reasons why parents are willing to pay is because the number of students in classes is small or ideal (Kennedy, 2021). Kennedy (2021) also explained that, students are able to get enough attention from their teachers in order to grasp the lesson learnt. Other than that, sufficient number of teachers are available in order to monitor as well as observe the students. Private schools were also able to use enough equipment needed for SOP compliance as they have stronger financial support. Compared to government schools, they have to rely on MOE for the SOP compliance preparation and even some teachers are unable to manage school fund efficiently (Zaki, 2020).

\section{Methodology}

Qualitative method was being used in collecting the data from participants. Interview was carried out on teachers from a private secondary school in Bangi, Selangor to collect the opinions and data. A total of six teachers participated in the research they and had at least three years of experience working in the private school. The data which had been collected by the researchers were being analysed and synthesised by using thematic analysis and narrative analysis (Abdullah et al., 2019). An interview through phone call was carried for each teacher as this is the most practical way during this pandemic. In addition, four general questions which related to the aim of study were being stated as the guidance for the researcher to conduct the interview session.

\subsection{Research Design}

Qualitative method was being used in collecting the data from participants. Interview was carried out on teachers from a private secondary school in Bangi, Selangor to collect the opinions and data. A total of six teachers participated in the research and had at least three years of experience working in the private school. The data which had been collected by the researchers were being analysed and synthesised by using thematic analysis and narrative analysis (What Is Narrative Analysis in Qualitative Research?-Delve, n.d.).

\subsection{Instrument}

An interview through phone call was carried for each teacher as this is the most practical way during this pandemic. There were a total of three demographic questions to be answered by the participants. In addition, five general questions which related to the aim of study were being stated as the guidance for the researcher to conduct the interview session.

\subsection{Participants}

A total of six teachers participated in the research. They were from an urban secondary private school in Bangi which is a religious school and the schooling 
hour is from 8.00 a.m. until 4.00 p.m. This means that the school has two meal breaktimes which are late breakfast and lunch. The school also has a prayer time which is from 1.00 p.m. until 2.00 p.m. The teachers were chosen purposively by the researcher because they are easily contactable by the researcher (Maidin \& Hamzah, 2010). They had at least two years of experience in teaching in the private school and all of them are teaching different subjects such as English, Mathematics, Islamic Education, Tajwid, History as well as Bahasa Melayu. Besides that, pseudonyms are used to replace the participants' full name for privacy and confidential purposes.

\subsection{Data Collection Procedure}

Data collection was conducted within a month. In March, the researcher was assigned with suggested topics and adapted on the topics to develop the study. In May, the researcher called the teachers individually to collect the data from each of the teachers. After interviewing, the researcher transcribed as well as translated the recorded call and put it down in words. After transcription, thematic analysis was used to categorise the collected data into different themes and a written report was completed in June.

\section{Findings and Discussion}

\subsection{Challenges Faced by the Teachers}

In this section, the researchers will discuss the challenges that are faced by the teachers, mainly teachers who were on duty in a particular week. These challenges were faced by the teachers during the course of their responsibilities. The challenges are divided into several parts and the researcher will use narrative form to discuss this section.

\subsubsection{Students' Attitude}

Most of the students obeyed the SOP when entering the school in the morning such as queued up to measure the temperature and only some students were reported to come late to the school. However, their attitude during school hour is not very satisfying according to the most teachers.

“... some of them, still doesn't want to obey SOP.” (Madam Mariam)

“... most of them doesn't comply to general SOP when the school finishes." (Mr. Zainal)

"Students are difficult to control especially when they're outside of the classroom. Some of them aren't wearing masks and need frequent reminders." (Mr. Izhar)

Mr. Izhar together with Miss Najiha also added that the number of sick students also increases even though the students were strictly advised to be absent if they get any illness.

"Their temperature was normal but later in the class, they were coughing and tired to study. This is so worrying." (Mr. Izhar) 
"According to the log book in sick bay, number of sick students is higher ..." (Miss Najiha)

Another teacher, Madam Liha complained that the students like to share their stationary without feeling guilty at all. Although they use sanitiser frequently but they were briefed before the school opens on the danger of sharing personal items. Madam Liha also stated that some of the students are not staying at the designated places before going back home. Their parents started to call the teachers if the students are not at the pickup points.

On the other hand, another teacher Miss Khaulah mentioned that students behaviour towards SOP compliance may be influenced because of too many rules and they might feel it is difficult to obey all of the rules.

\subsubsection{Physical Distancing}

All the teachers stated that some of the students did not practice physical distancing and can be seen clearly. This is worrying because if a student who got Covid positive, this will cause the other class students needed to be quarantined too unless the student did practice physical distancing. Therefore, only the students who were tested positive need to be quarantined and the other students should be able to attend school as explained by Dr. Anuar Ahmad, a lecturer from Universiti Kebangsaan Malaysia, in an online newspaper article (Mohd Reda, 2021). According to Madam Liha, some students still have the old habits where they like to be accompanied when they wanted to go to toilet or school shop. This shows that students still do not understand the safety of physical distancing.

\subsubsection{Breaktime}

During breaktime, students are not allowed to eat or buy at the canteen which is being done by most of the schools. The private school adapted by assigning some of the students from each class to pick the food from canteen to distribute in their class and this occurs twice in a day as they have two meal breaktime. Teachers were assigned to be on duty by observing the food distribution from the canteen. Most students who brought meal from home were very disciplined in SOP compliance compared to those who ordered from the school canteen (Mr. Izhar). Some students unable to follow the SOP during the breaktime as mentioned by these teachers.

"... always sit closely and share drinks among friends." (Miss Khaulah)

"... frequently change places to eat and like to share food among friends." (Miss Najiha)

"Always need to give warnings for those who like to share food and drinks..." (Madam Liha)

Lunch time and afternoon prayer time were included together at 1.00 p.m. until 2.00 p.m. and will be continued with another period of last lesson of the day. Teachers still were on duty during this period in order to observe them. Miss Khaulah complained that some students do not bring their own prayer mat 
and even share with other friends. Prayers were conducted at the school mosque and it is obligatory to use own prayer mat in order to prevent the spreading of infection. However, the mosque will be sanitised after school session had ended.

\subsubsection{Teachers' Duty on SOP}

A group of eight teachers were assigned to be on duty for each week where they need to be in charge of students' entrance in the morning, late breakfast time, lunch break and students departure in the afternoon every day. This is definitely different compared to before the pandemic where only one teacher needs to be on duty for one week. Most of the teachers said that their workload had increased when they were asked on what are the common challenge during SOP compliance at school.

“... I was struggling to prepare things for my kids too. During duty schedule, we have to go to school half an hour early..." (Madam Liha)

Madam Liha also experienced as the head of the team on duty and have to do extra responsibilities such as taking care of the thermal scanners and prepare weekly report. These can lead to more violation of SOP as the teachers started to experience pandemic fatigue (Hassan et al., 2021).

\subsection{Comparison between Private and Government Schools}

\subsubsection{Facilities and Workforce}

Most of the teachers disagree that their school has enough facilities and sufficient workforce.

"... I am fine with the facilities that we have but when comes to workforce, we are not enough." (Madam Mariam)

"In my opinion, facilities are not enough in a private school like us compared to government schools where they have more classrooms and high number of teachers." (Miss Najiha)

Both Mr. Izhar and Miss Khaulah disagree too that their school has enough labours to handle the SOP successfully.

Madam Liha explained that all the classrooms were fully occupied and packed with students after the table arrangement for physical distancing. She added that, it is difficult to conduct lessons especially when the lesson needs to be done collaboratively in groups. She also said about the usage of toilets since only few students are allowed to use in a time and there were long queues during breaktime especially before afternoon prayer. Miss Najiha also said the same and added that number of toilets are not enough and have to share the teachers toilet with the students.

“... more cleaners should be hired since more cleaning works and sanitisation need to be carried." (Miss Najiha)

On the other hand, Mr Izhar said that each class has smart television and weekly assembly can be stream through online for each class. Mr. Izhar agrees that facilities like this are better compared to government school where they will only listen through speakers since assembly and gatherings are not allowed ac- 
cording to SOP.

\subsubsection{SOP Compliance}

Although all the teachers said that the private school also face challenges similarly like the government schools, but when comes to SOP compliance, some of the teachers agree that government schools face harder challenges because of certain factors.

“... we have lower number of students and they are easy to control compared to students in government schools." (Mr. Izhar)

Madam Mariam added that students in government schools have worse disciplinary problems which will disrupt the teachers to carry out SOP compliance successfully.

\subsection{Suggestions and Recommendations}

Although there are inevitable challenges that need to be faced, but teachers have suggested some solutions which should be considered by the school. One of the teachers said that, accepting all students at once is seem impossible if the school want to carry out SOP compliance successfully. Dr. Azlin Norhaini Mansor from Universiti Kebangsaan Malaysia had stated similar opinion in a newspaper article where school reopening should be limited in order to curb the outbreak of infection (Bernama, 2021). Schools should do rotation of students alternately such as when the lower secondary students attend the school, lessons for the upper secondary should be done online from their home. Miss Najiha and Madam Liha disagree with this suggestion because it will only increase their workloads as they have to both physical and online lesson on the same day. They prefer that parents need to take responsibility if their children are not allowed to attend because of not obeying the SOP. Miss Khaulah said that it would be effective but the school cannot take such stern actions as they depend on the parents' fee for the school expenditure. Mr. Izhar shared his opinion that MOH should focus vaccination for schools first as they are the most vulnerable for Covid outbreak. Mr. Izhar added that some of the students attitude towards SOP compliance cannot be compromised because of their maturity but at the same time the government cannot abandon their education as they are the nation's next leaders.

\section{Reflection}

Overall, based on the interview from certain teachers in the private school, the researcher found out that the private schools do face challenges on SOP compliance. Although some of the interviewed teachers shared different opinions but this research able to get findings on the challenges of SOP compliance at the private school. The researcher perceived that these challenges may be shared by the teachers from government schools too. Surprisingly, certain features of the private school such as facilities and workforce, are not factors to carry out SOP without any obstacles. The private schools also face challenges despite having 
different management style as well as types of students. The teachers from the private school actually face more challenges as they have longer working hours. In conclusion, suggestion and recommendation should be considered as the MOE cannot fully depend on online classes. School children's education must be priority of our nation and everyone must play role in order to prevent another school closure because of COVID outbreak.

\section{Conflicts of Interest}

The authors declare no conflicts of interest regarding the publication of this paper.

\section{References}

Abdullah, M. Y., Hussin, S., \& Ismail, K. (2019). Implementation of Flipped Classroom Model and Its Effectiveness on English Speaking Performance. International Journal of Emerging Technologies in Learning, 14, 130-147. https://doi.org/10.3991/ijet.v14i09.10348

Abdullah, S., Mansor, A. A., Napi, N. N. L. M., Mansor, W. N. W., Ahmed, A. N., Ismail, M., \& Ramly, Z. T. A. (2020). Air Quality Status during 2020 Malaysia Movement Control Order (MCO) due to 2019 Novel Coronavirus (2019-nCoV) Pandemic. Science of the Total Environment, 729, Article ID: 139022. https://doi.org/10.1016/j.scitotenv.2020.139022

Ahmed, A., Aqeel, M., \& Aslam, N. (2021). COVID-19 Health Crisis and Prevalence of Anxiety among Individuals of Various Age Groups: A Qualitative Study. Journal of Mental Health Training, Education and Practice, 16, 58-66. https://doi.org/10.1108/JMHTEP-07-2020-0046

Anastasiou, S., \& Garametsi, V. (2021). Perceived leadership Style and Job Satisfaction of Teachers in Public and Private Schools. International Journal of Management in Education, 15, 58-77. https://doi.org/10.1504/IJMIE.2021.111817

Arifin, L. (2020, July). Ada Sekolah Berdepan Masalah Laksanakan SOP-NUTP. https://www.bharian.com.my/berita/nasional/2020/07/715016/ada-sekolah-berdepanmasalah-laksanakan-sop-nutp

Bernama (2021, April 23). Penutupan semua sekolah keputusan terbaik? Sinar Harian. https://www.sinarharian.com.my/article/135003/BERITA/Nasional/Penutupan-semuasekolah-keputusan-terbaik

Hassan, M. R., Sharizman, S., Abdul, S., \& Jeffree, M. S. (2021). Pandemic Fatigue: A Challenge in Combatting against COVID-19. Borneo Epidemiology Journal, 2, 19-21.

Huang, R., Liu, D., Tlili, A., Knyazeva, S., Chang, T. W., Zhang, X. et al. (2020). Guidance on Open Educational Practices during School Closures: Utilizing OER under COVID-19 Pandemic in line with UNESCO OER Recommendation. Beijing: Smart Learning Institute of Beijing Normal University.

https://educacion.udd.cl/aprendizaje180/files/2020/12/UNESCO-IITE-Guidance-on-O pen-Educational-Practices-during-School-Closures-2020.pdf

Idris, R., Abdul Mutalib, Z., \& Ibrahim, M. I. (2020, July 1). Sekolah dibuka mulai 15 Julai.

https://www.bharian.com.my/berita/nasional/2020/07/706158/sekolah-dibuka-mulai-1 5-julai

Kementerian Pendidikan Malaysia (2020). Garis Panduan Pengurusan Pembukaan Se- 
mula Sekolah (pp. 1-31). Kementerian Pendidikan Malaysia.

Kennedy, R. (2021). Lima Lagi Alasan Kenapa Anda Perlu Pertimbangkan Sekolah Swasta. https://ms.eferrit.com/5-lebih-banyak-sebab-kenapa-anda-perlu-pertimbangkan-sekola h-swasta/

Maidin, N. F., \& Hamzah, M. I. M. (2010). Learning to Develop Creativity and Innovation: A Case Study of Selected Schools. Procedia-Social and Behavioral Sciences, 7, 24-31. https://doi.org/10.1016/j.sbspro.2010.10.004

Malay Mail (2020). Secondary Schools Reopen after Three Months' Closure due to Covid-19. Malay Mail.

https://www.malaymail.com/news/malaysia/2020/06/24/secondary-schools-reopen-afte r-three-months-closure-due-to-covid-19/1878337

Mohamed-Haflah, N., Abdullah, S., \& Abdul-Rani, R. (2021). Coordinating a Postgraduate Orthopaedic Exam during the COVID-19 Pandemic. Malaysian Orthopaedic Journal, 15, 16-20. https://doi.org/10.5704/MOJ.2103.003

Mohd Reda, N. (2021, June 21). Analisis: Segerakan vaksin kepada guru antara langkah bendung COVID-19 disekolah. Bernama.com.

https://www.bernama.com/bm/b_fokus/news.php?id=1954583

Sababathy, M., Kalok, A. H. M., Hafizz, A. M. H. A., Sharip, S., Zainuddin, Z. M., \& Shafiee, M. N. (2021). Perception of Medical Students towards COVID-19 Outbreak and Movement Control Order (MCO) in Malaysia and Impact on Education (pp. 1-13). https://doi.org/10.21203/rs.3.rs-646716/v1

Tamin, N. H., \& Mohamad, M. (2020). Google Classroom for Teaching and Learning in Malaysia Primary School during Movement Control Order (MCO) due to Covid-19 Pandemic: A Literature Review. International Journal of Multidisciplinary Research and Publications, 3, 34-37.

Delve (n.d.) What Is Narrative Analysis in Qualitative Research? https://delvetool.com/blog/narrativeanalysis

Zaki, N. Z. (2020, November). Pengurusan Kewangan Sekolah dalam Tempoh PKP. Jurnal Refleksi Kepemimpinan, 3, 42-51.

http://myjms.mohe.gov.my/index.php/jrk/article/view/9890 